\title{
Analisis fatwa dewan syariah nasional No:98/DSN-MUI/XII/2015 tentang pedoman penyelenggaraan jaminan sosial kesehatan syariah dalam perspektif ekonomi islam (studi pada penyelenggaraan BPJS Kesehatan)
}

\author{
Rafiqi*; Ridwan; Jessica Pramudhita Rizkyka Senduk \\ Program Studi Ekonomi Islam, Jurusan Ilmu Ekonomi \\ *E-mail korespodensi: rafiqi@unja.ac.id
}

\begin{abstract}
This study aims to analyze the application of the National Sharia Council Fatwa No: 98/DSN-MUI/XII/2015 concerning Guidelines for the Implementation of Sharia Health Social Security in the Islamic Economic Perspective of the Health Social Security Administration Agency (BPJS). This type of research is descriptive qualitative research, a study that seeks to describe and explain the data obtained with secondary data. This study uses a library research approach, where the data sources are obtained from literature studies and various kinds of literature suitable for discussion, including the analysis of the fatwa of the Indonesian Ulema Council. This study indicates that the implementation of BPJS Kesehatan is not under the fatwa issued by the DSN-MUI according to the perspective of Islamic economics because it has not been maximized, and there are gaps in its implementation.
\end{abstract}

Keywords: Health BPJS, Fatwa DSN-MUI, Islamic economics.

\begin{abstract}
Abstrak
Penelitian ini bertujuan untuk menganalisis penerapan Fatwa Dewan Syariah Nasional No:98/DSN-MUI/XII/2015 tentang Pedoman Penyelenggaraan Jaminan Sosial Kesehatan Syariah dalam Perspektif Ekonomi Islam terhadap Badan Penyelenggaraan Jaminan Sosial (BPJS) Kesehatan. Jenis penelitian ini merupakan penelitian kualitatif deskriptif yaitu penelitian yang berusaha menggambarkan dan memaparkan data-data yang diperoleh dengan data sekunder. Penelitian ini mengunakan pendekatan studi kepustakaan (library research) yaitu sumber data diperoleh dari kajian-kajian pustaka dan berbagai macam literatur yang sesuai pembahasan, termasuk di dalamnya kajian fatwa Majelis Ulama Indonesia. Hasil penelitian ini menunjukan bahwa penerapan BPJS Kesehatan belum sesuai dengan fatwa yang dikeluarkan oleh DSN-MUI menurut perspektif ekonomi Islam dikarenakan belum maksimal dan terdapat ketimpangan di dalam pengimplementasiannya.
\end{abstract}

Kata Kunci: BPJS kesehatan, Fatwa DSN-MUI, Ekonomi islam

\section{PENDAHULUAN}

Hampir tidak ada satu pun negara di dunia ini yang tidak memprogramkan kemakmuran dalam bidang ekonomi bagi warga negaranya (Alim, 2010). Dalam pandangan ekonomi, suatu metode untuk mengurangi resiko dengan jalan memindahkan dan mengkombinasikan ketidakpastian akan adanya kerugian keuangan (financial) yaitu dengan asuransi (Darmawi, 2006). Dalam prakteknya di Indonesia, jaminan sosial berupa penanggulangan kesehatan bagi masyarakat diwujudkan dalam bentuk program JKN 
(Jaminan Kesehatan Nasional) yang diselenggarakan oleh Badan Penyelenggara Jaminan Sosial (BPJS). BPJS merupakan salah satu program pemerintah dengan sistem iuran wajib. Iuran masyarakat yang diwajibkan oleh pemerintah Indonesia ini cenderung menuai berbagai komentar. Masyarakat dituntut untuk membayar pengalihan resiko yang belum pasti terjadi dengan mengatasnamakan kesejahteraan dan apabila tidak terjadi resiko apapun di masa yang akan datang uang iuran ini dianggap sumbangan kepada negara tanpa adanya timbal balik.

Pada penerapannya terdapat fenomena-fenomena yang dirasa tidak sesuai harapan masyarakat. Contohnya adalah pada saat penerimaan klaim masyarakat harus mengalami begitu banyak proses yang sulit, ditambah lagi pemberian klaim yang dikeluhkan masyarakat sebab dianggap tidak memuaskan. Islam sendiri memandang segala hak masyarakat harus ditunaikan sebagaimana mestinya. Akad-akad yang dilakukan harus memiliki kejelasan dan tidak mengandung unsur kedzaliman. Ditambah lagi adanya ketidakjelasan dari akhir akad yang dilakukan, masyarakat selaku nasabah tidak mengetahui sampai kapan dia akan membayar iuran serta kapan dia akan menerima klaim dan seperti apa jaminan yang dia dapatkan nanti.

Salah satu hal yang paling menggemparkan adalah pada tahun 2015 adanya polemik Fatwa Majelis Ulama Indonesia (MUI) tentang BPJS Kesehatan yang dinilai masih belum sesuai dengan prinsip syariah, walaupun masih menjadi perdebatan namun ini bisa menjadi indikasi bahwa ada masalah dalam pengelolaan BPJS Kesehatan (Wirawan, 2020).

Asuransi ini juga menjual sesuatu yang bersifat gharar karena peserta mendapatkan pelayanan atau haknya jika mengalami resiko kesehatan, tetapi jika tidak mendapatkan resiko kesehatan atau terjadi suatu hal buruk yang menimpa peserta, premi yang dibayarkan tiap bulannya hangus begitu saja. Belum lagi dengan tidak transparansinya sistem denda yang kita tidak tahu kemana perginya uang denda yang dibayarkan. Sistem BPJS lainnya yaitu jika peserta meninggal dunia, maka haknya untuk mendapatkan dana BPJS gugur secara otomatis. Dalam islam, seseorang yang mempunyai harta benda atau sesuatu yang bernilai lainnya jika ia meninggal dunia maka haknya tersebut akan berpindah ke ahli warisnya.

Berbeda dengan prinsip akad dalam Islam. Dalam asuransi BPJS, peserta atau masyarakat dituntut dan diwajibkan untuk turut serta menjadi peserta asuransi BPJS yang bahkan banyak sekali kalangan yang tidak memahami tentang bagaimana dana iuran mereka kelola dan bahkan banyak sekali dari mereka yang tidak begitu memahami tentang manfaat apa saja yang akan mereka peroleh setelah menjadi peserta BPJS. Hal ini tentu bertentangan dengan prinsip akad 'anTaraadlin dalam Islam. Dalam Tafsir Al Misbah, 'an taradhin diartikan sebagai suatu kerelaan yang tersembunyi dalam lubuk hati, tetapi indikator dan tandatandanya dapat terlihat. Dengan kebijakan wajib bayar ini, mau tidak mau masyarakat tetap ikut serta menjalankan kebijakan yang telah ditetapkan oleh pemerintah, meskipun sebagian dari mereka merasa bahwa kebijakan tersebut dianggap bertentangan dengan apa yang mereka yakini, karena selama ini asuransi yang kita kenal kebanyakan menggunakan sistem asuransi konvensional, dimana didalamnya mengandung unsur riba, gharar, maysir dan sejenisnya yang sudah jelas dilarang oleh Islam (Istiqomah, 2016).

Pasca fatwa ulama Komisi Fatwa MUI tersebut, pada akhir 2015, Dewan

Syariah Nasional (DSN) MUI kemudian merilis fatwa Nomor 98/DSNMUI/XII/2015 tentang Pedoman Penyelenggaraan Jaminan Sosial Kesehatan

Syariah sebagai landasan atau konsep BPJS Kesehatan ('Athifa, 2018:36). Di dalam fatwa tersebut dijelaskan bagaimana agar BPJS Kesehatan dapat berpraktekkan secara syariah. 
Berangkat dari latar belakang yang telah dipaparkan di atas, maka dapat dirumuskan permasalahan penelitian, yaitu (1) bagaimana konsep penyelenggaraan BPJS Kesehatan di Indonesia secara umum, (2) bagaimana analisis penerapan fatwa Dewan Syariah Nasional No:98/DSN-MUI/XII/2015 tentang Pedoman Penyelenggaraan Jaminan Sosial Kesehatan Syariah terhadap BPJS Kesehatan dan (3) Bagaimana analisis penerapan BPJS Kesehatan berdasarkan fatwa Dewan Syariah Nasional No:98/DSNMUI/XII/2015 tentang Pedoman Penyelenggaraan Jaminan Sosial Kesehatan Syariah dalam perspektif ekonomi Islam.

\section{METODE}

Jenis penelitian ini adalah library research atau penelitian kepustakaan dengan metode deskriptif analisis, yaitu suatu studi yang digunakan dalam mengumpulkan informasi dan data dengan bantuan berbagai material yang ada di perpustakaan seperti dokumen, buku, majalah, kisah-kisah sejarah, dan lain sebagainya (Mardalis, 1995:24). Dalam pengumpulan datanya dilakukan melalui pengkajian terhadap literatur-literatur pustaka dengan objek yang dimaksud, yakni mengkaji buku-buku yang ada relevansinya dengan pembahasan.

Jenis dan sumber data yang penulis gunakan dalam penelitian ini yakni data sekunder. yaitu sumber data yang diperoleh dengan cara membaca, mempelajari dan memahami melalui media lain yang bersumber dari literatur, buku-buku, serta dokumen (Sugiono, 2010:17).

Teknik pengumpulan data yang diperlukan dalam penelitian ini yaitu, riset pustaka dan dokumentasi. Adapun teknik analisis data dengan metode analisis deskriptif: (1) content analysis atau analisis isi, (2) analisis kritis dan metode pembahasan: (1) metode induktif, (2) metode deduktif dan (3) metode komparasi.

\section{HASIL DAN PEMBAHASAN}

\section{Sistem akad}

Dalam upaya menghindari gharar, pada setiap kontrak asuransi syariah harus dibuat sejelas mungkin dan sepenuhnya terbuka. Keterbukaan itu dapat diterapkan pada dua sisi, yaitu baik pada pokok permasalahan maupun pada ketentuan kontrak. Tidak diperbolehkan terdapat elemen yang tidak jelas dalam pokok permasalahan ruang lingkup kontrak itu sendiri. Maysir (perjudian) timbul karena gharar. Peserta (tertanggung) mungkin memiliki kepentingan yang dipertanggungkan, tetapi apabila perpindahan resiko berisikan elemen-elemen spekulasi, maka tidak diperkenankan pada asuransi sosial dalam Islam.

Berdasarkan hal tersebut, jika yang menjadi penanggung dan tertanggung adalah sesama peserta, maka dalam hal ini yang terjadi adalah akad tabarru' (hibah/tolong menolong) sesuai dengan fatwa DSN No.98/-DSN-MUI/XII/2015 Tentang Pedoman Penyelenggara Jaminan Kesehatan Nasional Syariah. Namun, hal yang tidak sesuai dengan hibah sendiri dalam BPJS adalah tidak jelasnya pemilihan oleh peserta untuk memilih menggunakan akad tabarru' atau hibah yang dana seluruhnya untuk kepentingan peserta lain, tanpa mengharapkan kembali harta hibah itu atau memang diniatkan untuk kepentingan pribadi peserta, yakni dalam akad tabarru' (hibah), peserta memberikan hibah yang akan digunakan untuk menolong peserta lain yang terkena musibah. Sedangkan perusahaan bertindak sebagai pengelola dana hibah dan jika yang menjadi penanggung dan tertanggung adalah BPJS dan peserta, maka ini menyalahi prinsip dari BPJS Kesehatan yaitu gotong-royong dan juga BPJS Kesehatan menjanjikan suatu hal yang tidak pasti (pelayanan kesehatan) kepada masyarakat yang belum tentu akan sakit 
atau tidak (gharar). Seperti yang dijelaskan pada hadis Bukhari dan Muslim: "Setiap amalan itu hanyalah tergantung niatnya. Dan seseorang akan mendapat ganjaran sesuai dengan apa yang diniatkannya”. (HR. Bukhari \& Muslim dari Umar bin Khattab)"

Berdasarkan hal ini, penulis menyimpulkan bahwa BPJS Kesehatan belum jelas akadnya, selain poin pertama pada fatwa DSN No.98/DSN-MUI/XII/2015, disebutkan pada kentuan akad dan personalia hukum jenis akad yang digunakan, yaitu : Akad antara Peserta-lndividu dengan Peserta-Kolektif yang diwakili BPJS Kesehatan adalah akad hibah dalam rangka saling menolong sesama peserta (ta'awun).

\section{Sistem pembayaran premi}

Dalam hal pembayaran premi pada BPJS Kesehatan, terdapat pilihan pembayaran iuran dilihat dari tingkat kelas yaitu kelas 1, kelas 2 dan kelas 3 tergantung dari besar kecilnya iuran bulanan yang dibayar berdasarkan Peraturan Presiden Nomor 19 Tahun 2016 Tentang Perubahan Kedua atas Peraturan Presiden Nomor 12 Tahun 2013 Tentang Jaminan Kesehatan.

Iuran bagi Peserta Pekerja Penerima Upah yang bekerja pada Lembaga Pemerintahan terdiri dari Pegawai Negeri Sipil, anggota TNI, anggota Polri, pejabat negara, dan pegawai pemerintah non pegawai negeri sebesar 5\% dari Gaji atau Upah per bulan dengan ketentuan: $3 \%$ dibayar oleh pemberi kerja dan 2\% dibayar oleh peserta.

Iuran bagi Peserta Pekerja Penerima Upah yang bekerja di BUMN, BUMD dan Swasta sebesar 5\% dari Gaji atau Upah per bulan dengan ketentuan : 4\% dibayar oleh Pemberi Kerja dan 1\% dibayar oleh Peserta.

Untuk iuran peserta BPJS mandiri atau peserta BPJS Pekerja Bukan Penerima Upah (PBPU) adalah sebagai berikut : Sebesar Rp. 42.500,- (empat puluh dua ribu lima ratus rupiah) per orang per bulan dengan manfaat pelayanan di ruang perawatan Kelas III. Pemerintah teteap memberikan bantuan iuran sebesar Rp. 7.000, sehingga iuran BPJS Kesehatan kelas III yaitu sebesar Rp. 35.500 (tiga puluh lima ribu rupiah). Sebesar Rp. 100.000 ,- (seratus ribu rupiah) per orang per bulan dengan manfaat pelayanan di ruang perawatan Kelas II. Sebesar Rp.150.000,- (seratus lima puluh ribu rupiah) per orang per bulan dengan manfaat pelayanan di ruang perawatan Kelas I.

Iuran Jaminan Kesehatan bagi Veteran, Perintis Kemerdekaan, dan janda, duda, atau anak yatim piatu dari Veteran atau Perintis Kemerdekaan, iurannya ditetapkan sebesar 5\% (lima persen) dari 45\% (empat puluh lima persen) gaji pokok Pegawai Negeri Sipil golongan ruang III/a dengan masa kerja 14 (empat belas) tahun per bulan, dibayar oleh Pemerintah.

Berdasarkan pemahaman penulis, secara sosial sistem iuran BPJS Kesehatan berdasarkan asas gotong royong. Namun, jika dilihat dari aturan syariah penulis menemukan ketidaksesuaian dari adanya tingkat kelas dimana secara jelas membuat masyarakat berbeda sesuai dengan pilihan premi yang dibayarkan. Hal ini tidak sesuai pada fatwa DSN No.98-DSN-MUI/XII/2015 pada ketentuan iuran dan layanan pada poin ketiga, BPJS Kesehatan sebagai wakil Peserta-Kolektif wajib bertanggungjawab untuk mengupayakan agar besaran pembayaran imbalan dan membayarnya kepada fasilitas layanan kesehatan (Faskes) melalui sistem yang adil dan transparan.

\section{Sistem pencairan klaim}

Menurut peraturan menteri kesehatan No. 28 Tahun 2014 tentang pedoman pelaksanaan program jaminan kesehatan nasional menjelaskan mekanisme pencairan klaim oleh pihak BPJS pelaksanaan jaminan kesehatan, klaim pembayaran tidak dibayarkan oleh pemerintah, tetapi diserahkan pada pihak BPJS Kesehatan. Dokumen klaim akan diverifikasi oleh verifikator BPJS Kesehatan. Apabila pihak verifikator BPJS 
Kesehatan menyetujui maka klaim akan diganti oleh pihak BPJS Kesehatan, jika tidak disetujui maka klaim akan dikembalikan ke pihak rumah sakit. Pencairan dana yang diteruskan ke rumah sakit yang bersangkutan dan bukan ke rekening dari pasien atau peserta dari asuransi BPJS. Meskipun begitu, nantinya pasien atau peserta dari BPJS Kesehatan ini akan mendapatkan dana untuk penggantian biaya dari rumah sakit tersebut. Untuk bisa mengajukan klaim pada asuransi BPJS Kesehatan, maka pasien akan diminta untuk melengkapi beberapa dokumen yang menunjukkan keanggotaan pada asuransi BPJS Kesehatan.

Dari penjabaran diatas, terlihat bahwa untuk mengajukan klaim hanya dibutuhkan beberapa dokumen, tetapi melalui penelitian-penelitian terdahulu yang penulis analisis, banyak peserta yang mengeluhkan mekanisme dari pencairan klaim ini. Padahal, peserta telah menjalankan ketentuan sesuai dengan aturannya agar BPJS Kesehatan memberikan hak yang merupakan programnya dalam menjalankan kegiatan asuransi tersebut. Hal ini pun tidak dijalankan oleh BPJS Kesehatan sesuai dengan fatwa DSN No. 98-DSNMUI/XII/2015, dimana pada ketentuan iuran dan layanan pada poin pertama, BPJS Kesehatan harus memberikan kemudahan bagi semua peserta BPJS di seluruh wilayah Indonesia untuk mendapatkan pekayanan yang baik sesuai dengan hak mereka.

\section{Sistem kualitas pelayanan}

Dari beberapa penelitian terdahulu mengenai kualitas pelayanan BPJS Kesehatan yang penulis cermati, dapat dipahami bahwa BPJS Kesehatan membuat solusi mengatasi kendala dalam pelayanan yakni dengan menerima semua komplain dan keluhan dari peserta sehingga akhirnya keluhan tersebut dievaluasi kembali oleh BPJS Kesehatan.

Namun, persepsi peserta terkait pelayanan medis yang diberikan oleh pihak rumah sakit dianggap belum memuaskan. Hal tersebut dapat dilihat dari pelayanan medis yang diberikan kepada peserta yang dilakukan oleh salah satunya dokter spesialis yang belum sesuai dengan jenis penyakit, keramahan dokter, kesigapan dokter, serta kemampuan dokter dalam memberikan pelayanan medis yang belum memuaskan. Lalu persepsi pelayanan keperawatan yang diberikan oleh pihak rumah sakit dianggap berbelit-belit. Hal tersebut dapat dilihat dari pelayanan keperawatan yang belum sesuai, seperti keramahan perawat, kesigapan perawat ketika dibutuhkan serta kemampuan perawat dalam memberikan pelayanan keperawatan sangat minim. Persepsi selanjutnya yaitu terkait pelayanan rujukan yang diberikan oleh pihak rumah sakit juga dianggap belum sesuai. Peserta merasa dipersulit dalam memperoleh pelayanan kesehatan di rumah sakit sebagai pasien rujukan. Tidak adanya kontras pelayanan yang diberikan antara pasien rujukan maupun pasien gawat darurat.

Faktor yang menjadi kendala dalam pelayanan adalah banyaknya terjadi penunggakan pembayaran iuran, karena banyak peserta BPJS mengeluhkan pembayaran biaya pengobatan yang tak ditanggung sepenuhnya oleh BPJS. Peserta menilai, sesuai dengan Pasal 2 Undang-Undang Nomor 24 Tahun 2011, BPJS seharusnya menyelenggarakan sistem jaminan sosial berdasar asas kemanusiaan, manfaat dan keadilan sosial bagi semua rakyat Indonesia mendesak pemerintah segera memperbaiki sistem dan pelaksanaan BPJS Kesehatan.

Peserta juga berpendapat bahwa pemerintah harus memperhatikan pelayanan bagi masyarakat, agar pelayanan kesehatan yang layak dapat segera terpenuhi, dengan pola iuran yang wajib disetorkan peserta setiap bulannya lalu pihak BPJS akan memberikan pembiayaan kesehatan kepada peserta menandakan bahwa sejatinya diantara peserta terjadi ikatan saling menanggung.

Berdasarkan hal ini, sesuai dengan fatwa DSN No.98/DSN-MUI/XII/2015 Tentang Pedoman Penyelenggaraan Jaminan Sosial Kesehatan Syariah, penulis menyimpulkan belum sesuainya kualitas pelayanan oleh BPJS Kesehatan, diihat dari ketentuan iuran dan layanan poin keempat, BPJS Kesehatan wajib menunaikan kewajibannya dengan baik 
kepada Faskes sesuai perjanjian dan poin kelima, Faskes wajib memberikan layanan kesehatan kepada Peserta-Individu sesuai prinsip-prinsip syariah serta peraturan perundang-undangan yang berlaku; wajib menolong pasien dan dilarang menolak dan/atau mengabaikannya.

\section{Sistem denda/ sanksi}

Dikutip dari BPJS Kesehatan, sistem denda/sanksi adalah sebagai berikut :

1).Dalam hal keterlambatan pembayaran iuran Jaminan Kesehatan lebih dari 1 (satu) bulan sejak tanggal 10, penjamin peserta diberhentikan sementara. 2).Pemberhentian sementara penjamin peserta berakhir dan kepesertaan kembali aktif apabila peserta membayar iuran tertunggak paling banyak untuk waktu 12 bulan. 3).Dalam waktu 45 hari sejak status kepesertaan aktif kembali, peserta wajib membayar denda kepada BPJS Kesehatan untuk setiap pelayanan kesehatan rawat inap. 4).Denda sebagaimana yang dimaksud adalah sebesar 2,5\% (dua koma lima persen) dari setiap biaya pelayanan kesehatan untuk setiap bulan tertunggak, dengan ketentuan: a).Jumlah bulan tertunggak paling banyak 12 bulan, b).Besar denda paling tinggi Rp. 30.000 .000

Berdasarkan hal ini, penulis menyimpulkan ketidaksesuaian pada sistem sanksi/denda ini terdapat pada dikemanakannya uang denda para peserta yang dibayarkan, disini tidak ada kejelasan oleh BPJS Kesehatan apakah uang denda tersebut dipisahkan atau tidak dengan dana esrsdgthfj dan apakah uang denda tersebut masuk ke rekening bank konvensional. Hal ini tentu tidak sesuai dengan fatwa DSN No.98/DSNMUI/XII/2015 pada ketentuan sanksi poin pertama bagian d). dana sanksi (ta'zir) wajib diakumulasikan ke dalam dana jaminan sosial.

\section{Sistem pengelolaan dana}

Salah satu prinsip Sistem Jaminan Sosial Nasional, sebagaimana tercantum dalam Undang-undang No 40 Tahun 2004, adalah prinsip dana amanat. Pengelolaan Dana Jaminan Sosial, baik dalam bentuk dana operasional maupun dana investasi, diselenggarakan dengan mempertimbangkan aspek likuiditas, solvabilitas, kehati-hatian, keamanan dana dan hasil memadai. Pengelolaan dana dilaksanakan melalui suatu mekanisme yang merupakan kombinasi proses dan struktur, untuk menginformasikan, mengarahkan, mengelola dan memantau kegiatan organisasi dalam rangka mencapai tata kelola organisasi yang baik, yang mana hasil pengelolaan dana tersebut dipergunakan seluruhnya untuk pengembangan program dan sebesar-besarnya kepentingan peserta. Pengelolaan Dana Jaminan Sosial dan aset BPJS Kesehatan diatur dalam Peraturan Pemerintah Nomor 87 Tahun 2013 tentang Pengelolaan Aset Jaminan Sosial Kesehatan (sebagai penjelasan UU Nomor 24 Tahun 2011).

Lalu untuk premi per bulan yang dibayarkan oleh peserta BPJS Kesehatan yaitu melalui bank konvensional seperti, BRI, BCA, BNI, Mandiri dan BTN. Dalam hal ini, dana keluar masuk atau dana yang diinvestasikan dan dikelola oleh BPJS Kesehatan menggunakan bank konvensional. Di sinilah letak ketidaksesuaiannya, pada fatwa DSN No.98/DSN-MUI/XII/2015 ketentuan penampatan dan pengembangan dana jaminan sosial pada poin pertama disebutkan, BPJS Kesehatan wajib memiliki rekening penampungan DJS pada bank syariah.

Analisis penerapan BPJS Kesehatan berdasarkan fatwa DSN No.98/DSNMUI/XII/2015 Tentang Pedoman Penyelenggaraan Jaminan Sosial Kesehatan Syariah dalam Perspektif Ekonomi Islam

Berdasarkan tiga prinsip utama asuransi syariah yang telah penulis kemukakan pada landasan teori, yaitu: saling bertanggung jawab, saling bekerja sama atau saling membantu dan saling melindungi penderitaan satu sama lainnya. Islam mengajarkan bahwa sesama manusia harus memiliki tanggung jawab untuk saling membantu satu sama lain. Hal ini pun diterapkan dalam pelaksanaan jaminan asuransi kesehatan di BPJS 
Kesehatan, terlihat dalam prinsip yang dianutnya pun kegotongroyongan yang mana para peserta BPJS Kesehatan membayar iuran dengan akad hibah, yang akan digunakan untuk menolong peserta lain yang terkena musibah, sedangkan BPJS Kesehatan bertindak sebagai pengelola dana hibah. Meskipun pada dasarnya tidak semua peserta BPJS Kesehatan menyadari bahwa uang yang dibayarkan akan diputar untuk pembiayaan peserta BPJS Kesehatan lainnya.

Berdasarkan hal ini, BPJS Kesehatan telah melaksanakan atau menerapkan akad sesuai dengan isi fatwa yaitu akad tabarru'lta'awun dan telah memenuhi unsur 'aqidain. Akan tetapi masih belum ada istilah atau penamaan akad-akad syariah sehingga BPJS Kesehatan dinilai masih belum sesuai dengan ketentuan akadnya.

Di dalam khazanah pemikiran Islam, khususya terkait dengan sistem perekonomi Islam, dapat dipahami dengan mudah bahwa konsep jaminan dalam Islam adalah negara berkewajiban untuk memenuhi segala kebutuhan dasar tiap individu serta regulasi untuk mencapai kesejahteraan warganya (Antonio, 1994:148).

Terkait pembahasan tentang maqashid syariah tidaklah hanya sebagai pemuas nalar, tetapi juga memiliki tujuan praktis bagi iklim pemikiran dan kehidupan sosial umat Islam saat ini. Sebab, tujuannya adalah membantu umat Islam dalam memberikan aturan atau undang-undang terhadap berbagai kepentingan dan kemaslahatan yang ada, ketika munculnya berbagai kasus yang baru dan kompleks. Selain itu, untuk memutuskan satu pendapat hukum ketika terjadi perbedaan pandangan, Imam Al-Ghazali mengatakan bahwa, penjagaan terhadap maksud dan tujuan syariah adalah upaya mendasar untuk bertahan hidup, menahan faktor kerusakan dan mendorong terjadinya kesejahteraan (Ismanto, 2016:128).

Tujuan penetapan hukum atau yang sering dikenal dengan istilah maqashid syariah merupakan salah satu konsep penting dalam kajian hukum Islam. Karena begitu pentingnya maqashid syariah tersebut, para ahli teori hukum menjadikan maqashid syariah sebagai sesuatu yang harus dipahami oleh mujtahid yang melakukan ijtihad. Adapun inti dari teori maqashid syariah adalah untuk mewujudkan kebaikan sekaligus menghindarkan keburukan, atau menarik manfaat dan menolak mudharat.

Penulis mengambil kesimpulan bahwa penarapan BPJS Kesehatan belum sesuai dalam perspektif maqashid syariah, karena hal ini apabila dikaitkan dengan salah satu perlindungan yaitu perlindungan terhadap jiwa (hifz al-nafs). Maka belum sesuai karena Islam telah mensyariatkan atau mengatur hak-hak asasi manusia secara mendalam.

Zika Yunia Fauzia dan Abdul Kadir Riyadi (2014:66) mengatakan bahwa Islam mengatur hak hidup dengan segala macam jaminan yang cukup untuk menjaga hak tersebut. Islam membentuk masyarakatnya diatas fondasi dan dasar yang menguatkan dan memperkokoh hak-hak asasi manusia ini. Hak pertama dan paling utama yang diperhatikan islam ialah hak hidup, hak yang disucikan dan tidak boleh dihancurkan kemuliaannya dan di sinilah nilai jiwanya.

Kesimpulannya bahwa maqashid asy syariah adalah konsep untuk mengetahui hikmah (nilai-nilai dan sasaran syara' yang tersurat dan tersirat dalam Al-Qur'an dan Hadits) yang ditetapkan oleh Allah SWT terhadap manusia adapun tujuan akhir hukum tersebut adalah satu, yaitu mashlahah atau kebaikan dan kesejahteraan umat manusia baik di dunia maupun di akhirat.

\section{KESIMPULAN DAN SARAN}

\section{Kesimpulan}

Pemerintah membuat sebuah badan untuk menaungi rakyatnya yang diwujudkan dalam bentuk Jaminan Kesehatan (JKN) yang merupakan program dari Badan Penyelenggara Jaminan Sosial (BPJS) Kesehatan, dimana setiap warga negara Indonesia diwajibkan untuk menjadi peserta asuransi pada program jaminan kesehatan tersebut. 
Setiap warga negara Indonesia dan warga asing yang sudah bekerja di Indonesia selama minimal enam bulan wajib menjadi anggota BPJS. Setiap perusahaan wajib mendaftarkan pekerjanya sebagai anggota BPJS. Sedangkan orang atau keluarga yang tidak bekerja pada perusahaan wajib mendaftarkan diri dan anggota keluarganya pada BPJS.

Majelis Ulama Indonesia (MUI) pada tahun 2015 yang menyebutkan bahwa BPJS Kesehatan belum sesuai dengan ketentuan syariah, dilihat dari ketidakjelasan status iuran atau bahasa hukumnya, apakah termasuk hibah, wadiah atau sebagainya, sebab dalam Islam status dan kedudukannya harus jelas dan transparan. Lalu, kedudukan investasinya, apakah iuran yang dibayarkan menjadi milik peserta, pihak BPJS atau negara dan apakah didepositokan ke bank konvensional atau bank syariah, karena jika didepositokan ke dalam bank konvensional, maka sistem pada BPJS berpotensi riba. Maka dari itu, pada tahun yang sama Komisi Fatwa MUI beserta Pemerintah dan pihak BPJS mengagendakan rapat untuk membahas hal terkait, maka dikeluarkannya fatwa Dewan Syariah Nasional (DSN) - MUI Nomor 98/DSN-MUI/XII/2015 tentang Pedoman Penyelenggaraan Jaminan Sosial Kesehatan Syariah sebagai landasan atau konsep BPJS Kesehatan. Tetapi, penerapan fatwa tersebut pun belum dilaksanakan dengan baik oleh BPJS Kesehatan, baik dari segi teknis maupun sistemnya.

Jika dikaitkan dalam Islam, akad dalam asuransi ini bersifat gotongroyong atau saling tolong-menolong dalam kebaikan dan menanggulangi resiko kesehatan antar peserta. Akan tetapi, beberapa sistemnya dinilai bertolak belakang dari ketentuan syariah. Beberapa unsur pada prinsip asuransi syariah telah sejalan dengan sistem pada BPJS Kesehatan, yaitu saling bekerjasama/saling membantu, saling melindungi penderitaan orang lain tetapi masih ada unsur riba, maisyir dan gharar dilihat dari sistem akad yang masih belum jelas, kelas pada pembayaran premi, mekanisme klaim/pencairan, kualitas pelayanan, sistem denda yang uangnya tidak dipisahkan dengan dana jaminan sosial dan pengelolaan dana yang mana uang premi tersebut dikelola oleh bank konvensional yang di dalamnya mengandung bunga (riba).

\section{DAFTAR PUSTAKA}

Antonio, Muhammad. (1994). Prinsip dasar operasi asuransi tafakul dalam arbitrase islam di Indonesia (Badan Arbitrase Muamalat Indonesia, Jakarta.148

Athifa. (2018). Analisis Fatwa DSN-MUI No:98/DSN-MUI/XII/2015 tentang Pedoman Penyelenggaraan Jaminan Sosial Kesehatan Syariah, 1(1), 36

Fatwa Dewan Syariah Nasional No:98/DSN-MUI/XII/2015 tentang Pedoman Penyelenggaraan Jaminan Sosial Kesehatan Syariah dalam Perspektif Ekonomi Islam

Fauzia, dkk, (2014). Prinsip dasar ekonomi islam perspektif maqashid Al-syariah. 66-67 Ismanto, (2016). Kuat asuransi perspektif Maqashid Asy Syariah. Pustaka Pelajar: Yogyakarta, 128-130

Istiqomah. (2016). Tinjauan hukum islam terhadap praktik pengelolaan dana iuran asuransi BPJS Kesehatan. Skripsi. Program Studi Hukum Ekonomi Syariah, IAIN Salatiga.

Mardalis. (1995). Metode penelitian suatu pendekatan proposal (Bumi Aksara: Jakarta.

Peraturan Menteri Kesehatan No. 28 Tahun 2014 tentang Pedoman Pelaksanaan Program Jaminan Kesehatan Nasional

Wirawan, Jerome. (2015). Fatwa MUI tentang BPJS Picu Polemic https://www.bbc.com/indonesia/berita_indonesia/2015/07/150730_indonesia_bp js_mui, diakses Tanggal 12 Februari 2019. 